\title{
Preconditioning of Physalis angulata L. to maintain the viability of seeds
}

\author{
Manuela Oliveira de SOUZA ${ }^{1, *}$, Cíntia Luiza Mascarenhas de SOUZA ${ }^{1}$, Natalia dos Santos BARROSO ${ }^{1}$, \\ Claudinéia Regina PELACANI ${ }^{1}$

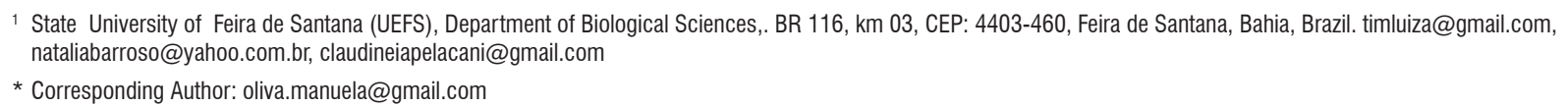

\section{ABSTRACT}

The important chemical and food properties conferred to $P$. angulata make it necessary to conduct studies in seed conservation. This study evaluated the effect of priming of $P$. angulata seed for varying periods and storage conditions. Lots of seeds were stored in a refrigerator and in ambient conditions for up to 24 months. Some of these seeds were primed before or after storage. The results show that there was variation in moisture content. The germination rate and germination rate index remained high in ambient conditions when primed up to 24 months.

KEYWORDS: storage environments, germination, longevity, priming.

\section{Pré-condicionamento de Physalis angulata L. na manutenção da viabilidade de sementes}

\section{RESUMO}

As importantes propriedades alimentícias e químicas atribuídas a $P$. angulata fazem dela uma espécie de grande valor para estudos de conservação de sementes. Este trabalho objetivou avaliar o efeito do pré-condicionamento osmótico de sementes de $P$. angulata submetidas a diferentes condiçóes e períodos de armazenamento. Lotes de sementes foram armazenados em condiçôes de ambiente e refrigerador até 24 meses. Parte dessas sementes foram osmocondicionadas antes ou após o armazenamento. Os resultados apresentados mostram que houve variação no teor de umidade. As sementes mantiveram taxas de germinação e índice de velocidade de germinação elevadas em ambiente quando osmocondicionadas até 24 meses.

PALAVRAS-CHAVE: ambientes de armazenamento, germinação, longevidade, osmocondicionamento. 
Physalis angulata L. belongs to the Solanaceae family and is widely used in folk medicine especially in countries in South America (Duke and Vasquez 1994; Hasrat et al. 1997). Many studies ascribe pharmacological properties to some of its chemical constituents. Among these are the immunomodulatory, antimicrobial and anticancer activities of extracts of P. angulata (Soares et al. 2006; Lopes et al. 2006).

The important chemical and food properties conferred to $P$. angulata have prompted the need to carry out studies in seed conservation. The commonest form of propagation is using seeds which have a high germination percentage (Rufato et al. 2008).

Seeds may deteriorate if there is a delay between collection and processing or during storage. Priming can maintain longevity because it controls the hydration of seeds, besides facilitating the repair of membranes, and synthesis of new proteins (Varier et al. 2010) providing benefits to the stored seeds. The benefits of this technique in $P$. angulata seeds have been observed when the seeds were exposed to salt stress (Souza et al. 2011) and also in the analysis of gene expression related to antioxidant enzymes (Souza 2012).

Despite their high capacity to remain viable for long periods, there is a lack of information about the time and how best to conserve the seeds of $P$. angulata. The aim of this study was to evaluate the effect of priming $P$. angulata seed for varying periods and storage conditions.

Mature fruits of $P$. angulata were collected manually in September 2009 from the Unidade Experimental Horto Florestal of the Universidade Estadual de Feira de Santana, Bahia. Seeds were primed in an aerated solution of polyethylene glycol (PEG 6000; Vilela et al. 1991) at an osmotic potential of $-1.2 \mathrm{MPa}$ for 10 days and kept in a growth chamber (Eletrolab 202, São Paulo, Brazil) at $35^{\circ} \mathrm{C}$
(Souza 2009). On the $10^{\text {th }}$ day the seeds were removed from the solution, washed and dried at room temperature until the initial weight. Some of seeds were stored in a refrigerator (at $5^{\circ} \mathrm{C}$ and relative humidity, $\mathrm{RH}$ of 29\%) (CRC 28ABANA, Consul, Joinville, Brazil) and some under ambient conditions ( $25^{\circ} \mathrm{C}$ and $\mathrm{RH} 72 \%$ ). Non-primed seeds (control) were stored in these same conditions for 6, 15, 21 and 24 months. At the end of the storage period some of the control seeds were removed and primed (as described) constituting the priming treatment after storage.

At the end of each storage period, the samples were separated randomly and processed to determine their moisture content and germination tests were carried out. Samples of 200 seeds were used to determine the water content gravimetrically, by drying for 17 hours at $107^{\circ} \mathrm{C}$ (ISTA 2007). Seed germination was performed in Petri dishes $(6 \mathrm{~cm} \times 6 \mathrm{~cm})$ with filter paper containing $3 \mathrm{ml}$ of distilled water (control). Germination tests were carried out in four replicates of 25 seeds per treatment and the germination was followed for 10 days at $35^{\circ} \mathrm{C}$ adjusted to a photoperiod of 12 hours. The seeds were considered germinated when radicles of at least $2 \mathrm{~mm}$ had emerged. The parameters evaluated were moisture content of seeds, germination rate (\%), average time (days) and germination rate index (seeds days ${ }^{-1}$ ).

The experimental design was completely randomized with 4 periods and 2 storage environments, two seed conditions - primed and non-primed. The data underwent analysis of variance, comparing the means by Tukey test at 5\% probability, using the statistical program SISVAR (Ferreira 2011).

The moisture content of the seeds of $P$. angulata showed variations during the 24 months of storage (Figure 1). Seeds

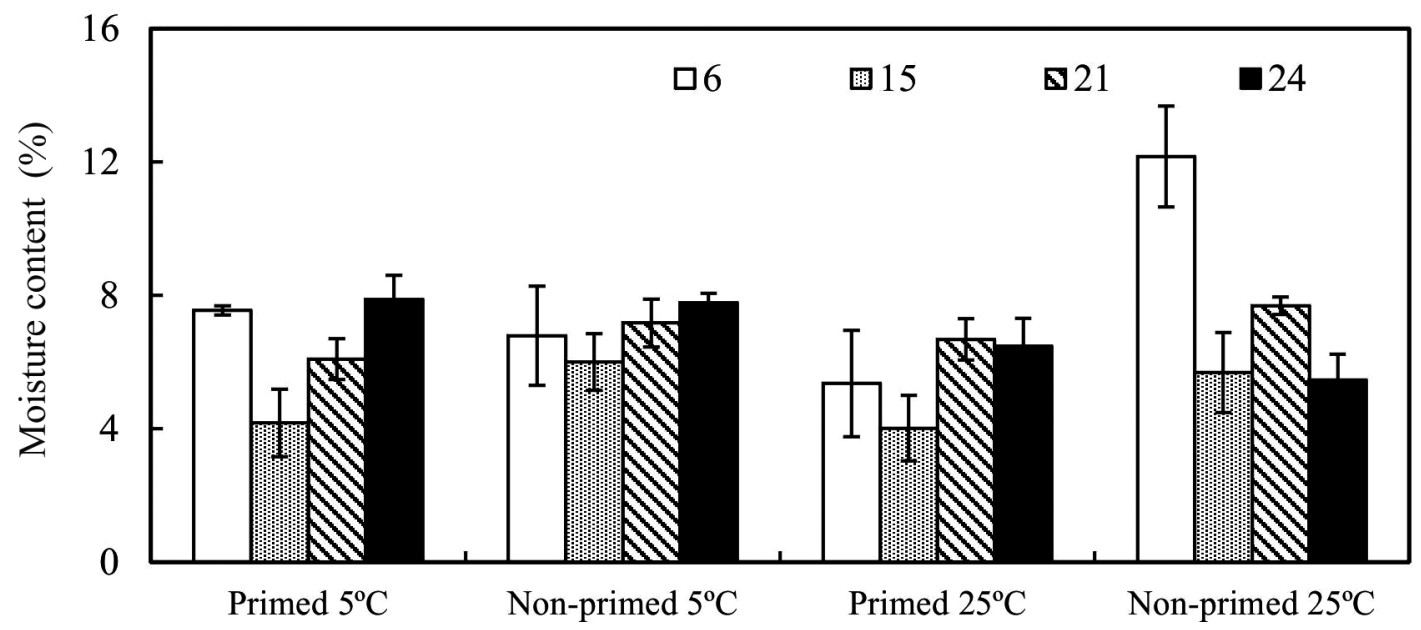

Figure 1 - Moisture content $P$. angulata seeds under different periods and storage conditions. 


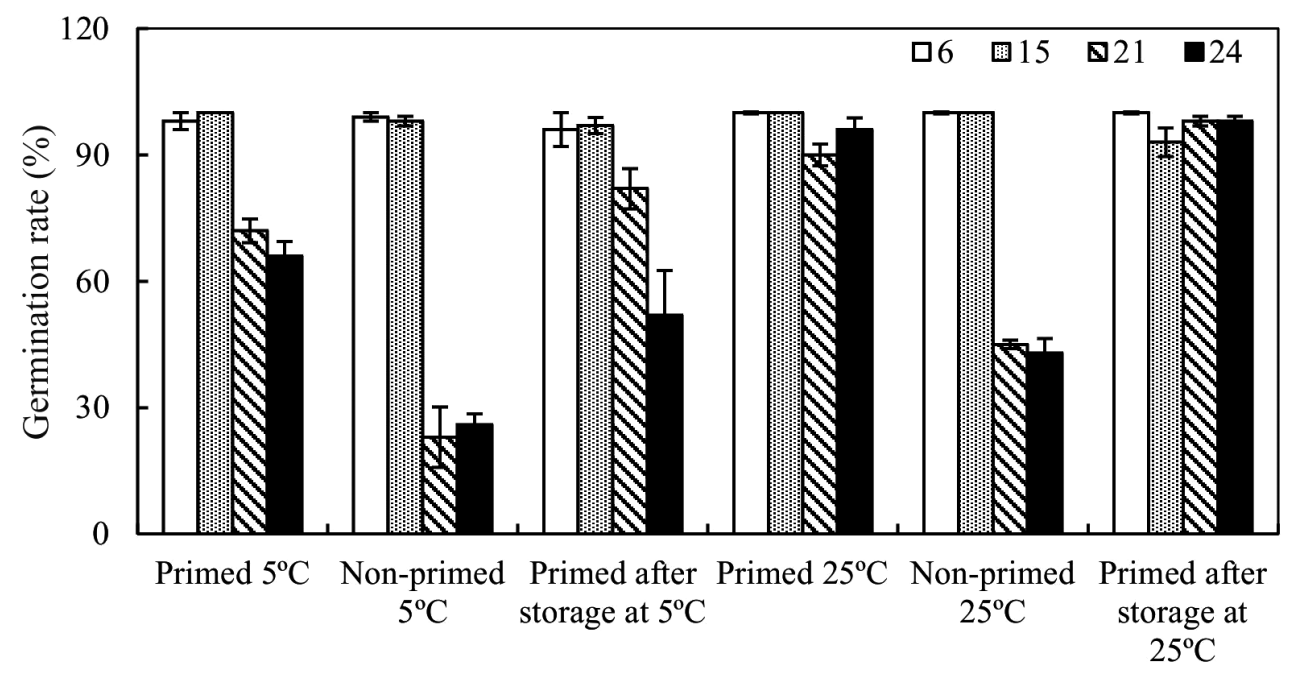

Figure 2 - Germination rate (\%) P. angulata seeds under different periods and storage conditions.

stored for 15 months maintained viability at a level which was very similar to those stored for a 6 month period (Figure 2).

It was observed that preconditioning together with temperature and relative humidity control are effective in maintaining the high germination rate of the seeds of $P$. angulata (Figures 1 and 2). In non-primed seeds the germination rate index decreased at 21 and 24 months regardless of the storage conditions (Table 1). The germination rate index was maintained high until 24 months when seeds were primed either before or after storage in ambient conditions (Table 1).

In these same conditions the seeds of $P$. angulata, even after 24 months storage germinated in a significantly shorter average time, compared with non-primed seeds or seeds kept at low temperatures.
It can be asserted that low temperatures (in a refrigerator) can be damaging to $P$. angulata seeds due to factors involved in the deterioration or even in the kinetic process of germination, regardless of the low water content of the seeds.

Preconditioning of seeds with osmotic substances is widely used to maintain seed vigor for plant species during storage. Studies into this nature have been developed with vegetable species and a crucial determinant of the performance of primed seeds is the choice of storage conditions. For example, cucumber seeds with $12 \%$ initial moisture content and stored under conditions of $70 \%$ relative humidity at $20^{\circ}$ $\mathrm{C}$ maintained a high germination percentage throughout a 12 month storage period (Alhamdan et al. 2011). Tomato seeds (Lycopersicon lycopersicum L.) primed for 7 days and stored at $10^{\circ} \mathrm{C}$ remained viable for 12 months, but at $30^{\circ}$ C the viability was reduced (Alvarado and Bradford 1988).

Table 1 - Average time (days), germination rate index (seeds day ${ }^{-1}$ ) P. angulata seeds under different periods and storage conditions.

\begin{tabular}{|c|c|c|c|c|c|c|}
\hline \multicolumn{7}{|c|}{ Conditions of seeds } \\
\hline Age (months) & $\begin{array}{l}\text { Primed } \\
5^{\circ} \mathrm{C}\end{array}$ & $\begin{array}{c}\text { Non-primed } \\
5^{\circ} \mathrm{C}\end{array}$ & $\begin{array}{l}\text { Primed after storage at } \\
\qquad 5^{\circ} \mathrm{C}\end{array}$ & $\begin{array}{l}\text { Primed } \\
25^{\circ} \mathrm{C}\end{array}$ & $\begin{array}{c}\text { Non- primed } \\
25^{\circ} \mathrm{C}\end{array}$ & $\begin{array}{l}\text { Primed after storage at } \\
5^{\circ} \mathrm{C}\end{array}$ \\
\hline \multicolumn{7}{|c|}{ Average time (days) } \\
\hline 6 & $2.68 \mathrm{Aa}$ & $2.94 \mathrm{Ab}$ & $3.27 \mathrm{Bb}$ & $2.04 \mathrm{Aa}$ & $2.56 \mathrm{Aa}$ & $2.87 \mathrm{Aa}$ \\
\hline 15 & $2.32 \mathrm{Aa}$ & $2.56 \mathrm{Aa}$ & $2.95 \mathrm{Aa}$ & $2.00 \mathrm{Aa}$ & $2.41 \mathrm{Aa}$ & $3.46 \mathrm{Bb}$ \\
\hline 24 & $4.48 \mathrm{Cc}$ & $3.25 \mathrm{Bb}$ & $3.33 \mathrm{Bb}$ & $2.50 \mathrm{Aa}$ & $3.23 \mathrm{Bb}$ & $2.20 \mathrm{Aa}$ \\
\hline \multicolumn{7}{|c|}{ Germination rate index (seeds day ${ }^{-1}$ ) } \\
\hline 6 & 10.12 Aa & $8.60 \mathrm{Ab}$ & $7.72 \mathrm{Ab}$ & $11.92 \mathrm{Aa}$ & $10.23 \mathrm{Aa}$ & $8.92 \mathrm{Bb}$ \\
\hline 15 & 11.24 Aa Aa & $10.00 \mathrm{Ab}$ & $8.70 \mathrm{Ac}$ & $12.50 \mathrm{Aa}$ & $10.80 \mathrm{Ab}$ & $6.87 \mathrm{Cc}$ \\
\hline 21 & $6.33 \mathrm{Bb}$ & $1.90 \mathrm{Bc}$ & $5.28 \mathrm{Bb}$ & $8.54 \mathrm{Ba}$ & $3.61 \mathrm{Bc}$ & $8.45 \mathrm{Ba}$ \\
\hline 24 & $3.89 \mathrm{Cb}$ & $2.04 \mathrm{Bc}$ & $4.08 \mathrm{Bb}$ & $10.06 \mathrm{Aa}$ & $3.38 \mathrm{Bb}$ & $11.44 \mathrm{Aa}$ \\
\hline
\end{tabular}

Means followed by the same capital letters in a column and lower case letters on the lines do not differ significantly by the Tukey test ( $p<0.05)$. 
These results demonstrate that the effect on longevity of seed priming may be species specific, depending on the nature of the stimulus and storage conditions.

The loss of germinability of orthodox seeds (desiccation tolerant) over storage time is represented by a negative sigmoid curve, but other variations are observed when seeds are exposed to unsuitable combinations of temperature and relative humidity (RH) or even under fluctuating temperature and RH in uncontrolled environmental conditions, for example.

In this study the relationship between low temperature and longevity could not be completely assessed. The effects of temperature and relative humidity of storage on variations in the responses of seeds of different species can be attributed to differences in their structural and biochemical composition (Rao et al. 2006). Furthermore, as $P$. angulata is a tropical species, it probably possesses biochemical mechanisms of seed protection that are best activated when primed seeds are associated with higher temperatures, which in this study corresponded to ambient temperature.

According to Varier et al. (2010) longevity provided by priming is related to the gene expression associated with antioxidant mechanisms. Deterioration of the seed is related to loss of membrane integrity, changes in enzymatic activity, decrease in protein, nucleic acid synthesis and DNA damage (McDonald 1999). Priming may reverse some of the events induced by aging and thereby improve seed performance (Varier et al. 2010).

Rosseto et al. (2002) evaluated three commercial batches of tomato seeds. The results showed that immediately after treatment, and stored up to 60 days, the primed tomato seeds had higher germination and vigor, regardless of the batch. However, after 120 days of storage, the primed seeds of one of the cultivars showed higher germination and vigor than non-primed seeds.

The results presented in this work show that priming is an efficient technique for the maintenance and restoration of vigor of $P$. angulata, for up to 24 months under ambient conditions.

\section{ACKNOWLEDGMENTS}

This research was supported by grants from Fundaçáo de Amparo do Estado da Bahia (FAPESB) and Conselho Nacional de Desenvolvimento Científico e Tecnológico (CNPq), Brazil.

\section{REFERENCES}

Alhamdan, A.M.; lsadon, A.A.; Khalil, S.O.; Wahb-Allah, M.A.; El Nagar, M.; Ibrahim, A.A. 2011. Influence of storage conditions on seed quality and longevity of four vegetable crops. AmericanEurasian Journal Agricultural and Environmental Science, 11: 353-359.

Alvarado, A.D.; Bradford, K.J. Priming and storage of tomato (Lycopersicon lycopersicum) seeds: I. 1988. Effects on storage temperature on germination rate and viability. Seed Science and Technology, 16: 601-612.

Duke, J.A.; Vasquez, R. 1994. Amazonian ethnobotanical dictionary. CRC Press, Florida, 1994, 215p.

Ferreira, D.F. 2011. Sisvar: a computer statistical analysis system. Ciência e Agrotecnologia, 35: 1039-1042.

Hasrat, J.A.; De Backer, J.P.; Vauquelin, G.; Vlietinck, A.J. 1997. Medicinal plants in Suriname: Screening of plant extracts for receptor binding activity. Phytomedicine, 4: 59-65.

ISTA. International Rules for Seed Testing Association, Bassersdorf, Switzerland, 2007.

Lopes, D.C.D.X.P.; Freitas, Z.M.F.; Santos, E.P.; Tomassini, T.C.B. 2006. Atividade antimicrobiana e fototóxica de extratos de frutos e raízes de Physalis angulata L. Revista Brasileira de Farmacognosia, 6: 206-210.

McDonald, M.B. 1999. Seed deterioration: Physiology, repair and assessment. Seed Science Technology, 27:177-237.

Rao, R.G.S.; Singh, P.M.; Rai, M. 2006. Storability of onion seeds and effects of packaging and storage conditions on viability and vigour. Scientia Horticulturae, 110:1-6.

Rosseto, C.A.V.; Lima, T.M.; Nakagawa, J. 2002. Qualidade fisiológica e potencial de armazenamento de sementes de tomate submetidas ao condicionamento osmótico. Horticultura Brasileira, 20: 630-634.

Rufato, L.; Rufato, A.R.; Schelemper, C.; Lima, C.S.M.; Kretzschmar, A.A.A. 2008. Aspectos técnicos da cultura da Physalis. CAV/UDESC, Lages, 2008, 100p.

Soares, M.B.P., Brustolim, D. Santos, L.A.; Bellintani, M.C.; Paiva, F.P., Ribeiro, I.M., Tomassini T.C.B; Santos, R.R. 2006. Physalins B, F e G, seco-steroids purified from Physalis angulata L., inhybity lymphocyte function and allogeneic transplant rejection. International Immunopharmacology, 6: 408-414.

Souza, M.O de. 2012. Expressão diferencial de genes em sementes osmocondicionadas e plântulas de Physalis angulata L. e prospecção de constituintes seco-esteroidais em plantas submetidas a estresse abiótico. Tese de Doutorado, Universidade Estadual de Feira de Santana, Feira de Santana. 92p.

Souza, C.L.M. 2009. Germinabilidade de sementes de Physalis angulata L. (Solanaceae) sob condiçôes de estresses abióticos. Dissertação de Mestrado, Universidade Estadual de Feira de Santana, Feira de Santana. 53p.

Souza, M.O.S.; Souza, C.L.M.; Pelacani, C.R. 2011. Germinação de sementes osmocondicionadas e náo osmocondicionadas e crescimento inicial de Physalis angulata L. (Solanaceae) em ambientes salinos. Acta Botanica Brasilica, 25:105-112.

Varier, A.; Vari, A.K.; Dadlani, M. 2010. The subcellular basis of seed priming. Current Science, 99: 450-456.

Villela, F.A.; Doni Filho, L.D; Sequeira, E.L. 1991. Tabela de potencial osmótico em função da concentração de polietilenoglicol 6.000 e da temperatura. Pesquisa Agropecuária Brasileira, 26: 1957-1968.

Recebido em 24/03/2013

Aceito em 29/04/2013 